\title{
Pengaruh tingkat suku bunga dan kurs terhadap harga saham industri pertambangan batubara di Bursa Efek Indonesia periode 2014-2017
}

\author{
Ahfazhi*; Fitriaty; Tona Aurora Lubis \\ Program Studi Manajemen Fakultas Ekonomi dan Bisnis Universitas Jambi \\ *E-mail Korespondensi: ahfazhiazi@gmail.com
}

\begin{abstract}
This study aims to examine the effect of the interest rate of Bank Indonesia and the exchange rate on the stock prices of the coal industry listed on the Indonesian securities exchange for 2014-2017period empirically. Data used in this study are multiple linear analyses and hypotheses. The independent variable is the interest rate of Bank Indonesia. The dependent variable is exchange rates at the coal mining industry stock price for 20142017. Data used in this study are secondary data obtained from the Indonesian stock exchange (IDX). The testing of the hypothesis in this study was tested using SPSS 23. The results showed that the interest rate of Indonesian banks had an effect of $18.75 \%$ and an effective exchange rate of $44.22 \%$, with a significant negative impact on the share price of the coal mining industry listed on the Indonesian stock exchange in 2014- 2017.
\end{abstract}

Keywords: interest rates, exchange rate, stock price.

\begin{abstract}
Abstrak
Penelitian ini bertujuan untuk menguji pengaruh suku bunga Bank Indonesia dan nilai tukar terhadap harga saham industri batubara yang terdaftar di Bursa Efek Indonesia periode 2014-2017 secara empiris. Data yang digunakan dalam penelitian ini adalah analisis linier berganda dan hipotesis dengan variabel bebas adalah suku bunga Bank Indonesia dan variabel terikatnya adalah nilai tukar pada harga saham industri pertambangan batubara periode 2014-2017. Data yang digunakan dalam penelitian ini adalah data sekunder yang diperoleh dari Bursa Efek Indonesia (BEI). Pengujian hipotesis dalam penelitian ini diuji dengan menggunakan SPSS 23. Hasil penelitian menunjukkan bahwa tingkat suku bunga perbankan di Indonesia berpengaruh sebesar $18,75 \%$ dan berpengaruh kurs sebesar 44,22\% yang berpengaruh negatif signifikan terhadap harga saham industri pertambangan batubara yang terdaftar di Bursa Efek Indonesia tahun 2014-2017.
\end{abstract}

Kata kunci: suku bunga, nilai tukar, harga saham.

\section{PENDAHULUAN}

Memperoleh keuntungan merupakan tujuan utama dari setiap perusahaan. Untuk memperoleh keuntungan, perusahaan melakukan aktivitas produksi dan hasil penjualan produksi dikurangi dengan biaya produksi, dari sanalah keuntungan perusahaan didapatkan. Untuk melakukan kegiatan produksi, perusahaan membutuhkan dana. Dana yang berasal dari dalam perusahaan adalah modal sendiri sedangkan dana yang berasal dari luar perusahaan diperoleh dari pasar keuangan atau financial market. Pasar modal 
adalah sarana investasi karena digunakan sebagai tempat yang mempertemukan antara pihak yang memiliki kelebihan dana dengan pihak yang membutuhkan dana dengan cara memperjualbelikan sekuritas. Menurut Hartono (2016) investasi adalah sebagai penundaan konsumsi sekarang untuk dimasukkan ke aktiva produktif selama periode waktu tertentu.

Perusahaan investasi adalah perusahaan yang menyediakan jasa keuangan dengan cara menjual sahamnya ke publik dan menggunakan dana yang diperoleh untuk diinvestasikan kedalam portofolionya. Ini berarti bahwa perusahaan investasi membentuk portofolio (diharapkan portofolio optimal) dan menjualnya secara eceran kepada publik dalam bentuk saham-sahamnya.

Menurut Tandelilin (2001) dalam melakukan analisis penilaian saham, investor biasanya melakukan analisis fundamental secara "top-down" untuk menilai prospek perusahaan. Pertama kali perlu dilakukan analisis terhadap faktor- faktor makro ekonomi yang mempengaruhi kinerja sseluruh perusahaan, kemudian dilanjutkan dengan analisis industri dan pada akhirnya dilakukan analisis terhadap perusahaan yang mengeluarkan sekuritas yang bersangkutan untuk menilai apakah sekuritas yang dikeluarkannya menguntungkan atau merugikan bagi investor.

Menurut Tandelilin (2001) lingkungan ekonomi makro adalah lingkungan yang mempengaruhi operasi perusahaan sehari-hari. Kemampuan investor dalam memahami dan meramalkan kondisi ekonomi makro di masa mendatang, akan sangat berguna dalam pembuatan keputusan investasi yang menguntungkan. Untuk itu, seorang investor harus memperhatikan beberapa indikator ekonomi makro yang bisa membantu mereka dalam memahami dan meramalkan kondisi ekonomi makro.

Menurut Tandelilin (2001), faktor-faktor ekonomi makro secara empiris telah terbukti mempunyai pengaruh terhadap perkembangan investasi di beberapa negara. Beberapa faktor ekonomi makro yang berpengaruh terhadap investasi di suatu negara, sebagai : tingkat Produk Domestik Bruto (PDB), laju pertumbuhan inflasi, tingkat suku bunga dan nilai tukar mata uang (exchange rate).

Tingkat suku bunga merupakan salah satu intrumen kebijakan yang dikeluarkan Bank Indonesia sebagai bank sentral yang menjalankan kebijakan moneter. BI Rate adalah suku bunga kebijakan yang mencerminkan sikap atau stance kebijakan moneter yang ditetapkan oleh bank Indonesia dan diumumkan kepada publik. BI Rate diumumkan oleh Dewan Gubernur Bank Indonesia setiap Rapat Dewan Gubernur bulanan dan diimplementasikan pada operasi moneter yang dilakukan Bank Indonesia melalui pengelolaan likuiditas (liquidity management) di pasar uang untuk mencapai sasaran operasional kebijakan moneter. www.bi.go.id).

Pada tahun 2014-2015 tingkat suku bunga SBI cenderung stabil pada 7.50\% sedangkan pada tahun 2016 tingkat suku bunga turun pada $5.25 \%$ dan kembali menurun pada $4.25 \%$ pada tahun 2014. Peningkatan suku bunga akan menyebabkan berkurangnya minat para investor untuk menanamkan modalnya di pasar modal, karena mereka lebih tertarik untuk menginvestasikan uangnya di Lembaga-lembaga keuangan tanpa risiko. Begitu pula sebaliknya penurunan tingkat suku bunga akan menyebabkan para investor cenderung berinvestasi di pasar modal guna memperoleh return yang lebih tinggi. Sehingga apabila tingkat suku bunga naik maka permintaan investor terhadap saham akan turun dan ini akan mengakibatkan harga saham akan turun apabila tingkat suku bunga turun maka permintaan akan saham naik akan mengakibatkan harga saham naik.

Menurut Tandelilin (2001) tingkat suku bunga yang terlalu tinggi akan 
mempengaruhi nilai sekarang (present value) aliran kas perusahaan, sehingga kesempatan-kesempatan investasi yang ada tidak akan menarik lagi. Tingkat suku bunga yang tinggi juga akan meningkatkan biaya modal yang harus ditanggung perusahaan. Disamping itu tingkat suku bunga yang tinggi juga akan menyebabkan return yang disyaratkan investor dari suatu investasi akan meningkat. Untuk mengetahui tingkat suku bunga SBI berdasarkan hasil dari Rapat Dewan Gubernur Periode Januari 2014 Desember 2017 dapa dilihat pada tabel dibawah ini.

Nilai tukar merupakan salah satu harga terpenting dalam perekonomian terbuka mengingat pengaruhnya yang demikian besar bagi transaksi berjalan maupun variabelvariabel makro lainya, oleh karena itulah nilai tukar merupaka sebuah harga aktiva atau harga asset (asset price), sehingga prinsip-prinsip pengaturan harga asset-aset lainnya juga berlaku dalam pengaturan nilai tukar. (Salvatore, 2007).

Nilai tukar mata uang Rupiah terhadap USD (US Dollar) adalah sejumlah mata uang Rupiah yang harus dikeluarkan untuk membeli atau dikonversikan dengan sejumlah mata uang USD. Nilai tukar mata uang Rupiah yang semakin menguat terhadap USD mengartikan bahwa semakin baiknnya kodisi makro ekonomi berakibat pada semakin bertumbuhnya kepercayaan investor untuk menginvestasikan dananya di Indonesia.

Begitu pula sebaliknya, melemahnya nilai tukar mata uang Rupiah terhadap USD mengartikan semakin menurunnya kepercayaan investor untuk menginvestasikan dananya di Indonesia. Bertumbuhnya kepercayaan investor menyebabkan terjadinya peningkatan jumlah permintaan saham dan apabila permintaan akan saham meningkat maka harga saham akan naik. Begitu pula sebaliknya, menurunnya kepercayaan investor menyebabkan menurunnya jumlah permintaan saham apabila permintaan akan saham menurun maka harga saham juga akan turun.

Saat ini hampir semua negara menganut perekonomian terbuka. Perekonomian terbuka merupakan suatu perekonomian suatu negara yang terlibat secara luas dalam perdagangan antar negara (internasional). Artinya mereka melakukan kerjasama dalam bidang ekonomi, dan melakukan ekspor dan impor.

Sub sektor industri pertambangan merupakan salah satu sub sektor yang terdaftar di Bursa Efek Indonesia. Industri ini merupakan salah satu sektor yang memegang peranan penting dalam perkembangan perekonomian di Indonesia. Aktivitas Industri Pertambangan Batu bara yang berhubungan dengan kegiatan ekspor dan impor, terutama pada kegiatan ekspor dimana harga batu bara dan volume ekspor batu bara menurun, sehingga tingkat suku bunga dan perubahan nilai tukar sangat mempengaruhi pendapatan Industri Pertambangan Batu bara yang pada akhirnya mempengaruhi harga saham industry tersebut.

Berdasarkan latar belakang diatas peneliti tertarik mengambil judul "Pengaruh tingkat suku bunga dan kurs terhadap harga saham industri petambangan Batubara di Bursa Efek Indonesia Periode 2014-2017".

\section{TINJAUAN PUSTAKA}

\section{Manajemen Keuangan}

Menurut Kasmir (2010) manajemen keuangan adalah aktivitas manajemen keuangan berkaitan erat dengan pengelolaan keuangan perusahaan, tersamuk lembaga yang berhubungan erat dengan sumber pendanaan dan investasi keuangan perusahaan serta instrument keuangan. 


\section{Investasi}

Menurut Hartono (2016) investasi dapat didefinisikan sebagai penundaan konsumsi sekarang untuk dimasukkan ke aktiva produktif selama periode waktu yang tertentu.

\section{Saham}

Menurut Fahmi (2014) saham adalah tanda bukti penyertaan kepemilikan modal/dana pada suatu perusahaan. Kertas yang tercantum dengan jelas nilai nominal, nama perusahaan dan diikuti dengan hak dan kewajiban yang dijelaskan kepada setiap pemegangnya. Persediaan yang siap untuk dijual.

Menurut Tandelilin (2001) saham merupakan bukti bahwa kepemilikan atas asetaset perushaan yang menerbitkan saham. Dengan memiliki saham suatu perusahaan, maka investor akan mempunyai hak terhadapa pendapatan dan kekayaan perusahaan, setelah dikurangi dengan pembayaran semua kewajiban perusahaan. Saham merupakan salah satu jenis sekuritas yang cukup popular diperjualbelikan di pasar modal.

\section{Harga saham}

Harga saham adalah uang yang dikeluarkan untuk memperoleh bukti penyertaan atau pemilikan suatu perusahaan (Anoraga, 2006). Menurut Darmadji dan Fakhrudin (2012) harga saham adalah harga yang terjadi di bursa pada waktu tertentu. Harga saham bisa berubah naik atau pun turun dalam hitungan waktu menit bahkan dapat berubah dalam hitungan detik. Hal tersebut dimungkinkan karena tergantung dengan permintaan dan penawaran antara pembeli saham dengan penjual saham.

\section{Suku bunga}

Tingkat suku bunga merupakan salah satu intrumen kebijakan yang dikeluarkan Bank Indonesia sebagai bank sentral yang menjalankan kebijakan moneter. BI Rate adalah suku bunga kebijakan yang mencerminkan sikap atau stance kebijakan moneter yang ditetapkan oleh bank Indonesia dan diumumkan kepada publik. BI Rate diumumkan oleh Dewan Gubernur Bank Indonesia setiap Rapat Dewan Gubernur bulanan dan diimplementasikan pada operasi moneter yang dilakukan Bank Indonesia melalui pengelolaan likuiditas (liquidity management) di pasar uang untuk mencapai sasaran operasional kebijakan moneter.(www.bi.go.id).

\section{Nilai tukar mata uang (Kurs)}

Menurut Laurensia Sonta. P dan Desi Anita (2014) dalam penelitiannya yang berjudul "Analsis Pengaruh Operating Profit Margin (OPM), Return On Equity (ROE), Earning Per Share (EPS), Nilai Tukar Rupiah (Kurs) dan Iniflasi Terhadap Harga Saham Pada Perusahaan Garment dan Tekstil yang Terdaftar di Bursa Efek Indonesia (BEI)”, nilai tukar rupiah (kurs) adalah perbandingan nilai antara mata uang yang menunjukkan harga suatu mata uang jika dibandingkan dengan mata uang lain. Menurut Hamdan Prabowo, Budi Wahono, dan M. Khoirul ABS (2016) dalam penelitiannya yang berjudul "Pengaruh Inflasi, Tingkat Suku Bunga, Nilai Tukar Rupiah Terhadap Dollar Amerika Terhadap Harga Saham (Perusahaan Industri Tekstil dan Garmen Yang tercatat di Bursa Efek Indonesia Periode Tahun 2013-2015)", nilai tukar atau kurs (exchange rate) adalah harga suatu mata uang terhadap mata uang asing, seberapa mata uang terhadap mata uang asing, seberapa mata uang domestik dihargai oleh mata uang asing. 


\section{METODE}

\section{Populasi}

Populasi dari penelitian ini adalah perusahaan-perusahaan yang pertambangan batu bara yang terdaftar di Bursa Efek Indonesia. Perusahaan pertambangan batu bara yang menjadi populasi dalam penelitian ini selama periode Januari 2014 sampai Desember 2017 yang terdiri dari 23 perusahaan.

\section{Sampel}

Pengambilan sampel dalam penelitian ini dilakukan dengan menggunakan Purposive Sampling, dimana pengambilan sampel didasarkan pada pertimbanganpertimbangan tertentu. Adapun yang menjadi kriteria pengambilan sampel dalam penelitian ini adalah Daftar sektor pertambangan batubara yang terdaftar di Bursa Efek Indonesia (BEI) selama tahun 2014-2017.Sektor pertambangan batu bara yang sahamnya aktif diperdagangkan di Bursa Efek Indonesia (BEI) secara berturut-turut selama tahun 2014-2017.Saham diperdagangkan minimal 1 bulan sekali Adapun sampel yang memenuhi syarat dan menjadi objek penelitian dalam penelitian ini adalah berjumlah 21 perusahaan yang konsisten terdaftar di Bursa Efek Indonesia selama periode Januari 2014 sampai Desember 2017.

\section{Jenis data}

Jenis data yang digunakan dalam penelitian ini adalah data sekunder yaitu berupa data hasil olahan dari pihak lain. Pada penelitian ini data yang diambil adalah berupa data yang diambil dari Bank Indonesia melalui situs www.bi.go.id yang terdiri dari data laporan tingkat suku bunga Sertifikat Bank Indonesia, dan kurs nilai tukar Rupiah terhadap USD dan data harga saham pada industri pertambangan batubara selama periode 2014-2017 yang diambil melalui situs www.idx.co.id.

\section{Sumber data}

Sumber data yang diperoleh dalam penelitian ini adalah data sekunder yang bersumber dari :1).Harga saham penutup bulanan yang diterbitkan oleh Bursa Efek Indonesia melalui situs www.idx.co.id, 2).Bank Indonesia yang dapat dilihat melalui situs, 3).Berbagai literature yang berkaitan dengan penelitian ini.

\section{Metode pengumpulan data}

Metode pengumpulan data yang digunakan penulis dala penelitian ini adalah Library Research yaitu suatu metode pengumpulan data sekunder yang berupa data harga saham bulanan, tingkat suku bunga Sertifikat Bank Indonesia, kurs nilai tukar mata uang Rupiah terhadap USD, buku-buku, jurnal, serta penelitian terdahulu yang berhubungan dengan masalah yang diteliti.

\section{Analisis data}

\section{Analisis trend horizontal}

Digunakan untuk menghitung perkembangan tingkat suku bunga SBI, nilai kurs tengah Rupiah tehadap USD terhadap harga saham pada industry pertambangan batubara adapun rumus yang digunakan adalah sebagai berikut: 
Perkembangan $=\frac{T a-T d}{T d} \times 100 \%$

Keterangan :

Ta : Data tahun yang dianalisis

Td : Data tahun dasar

\section{Uji asumsi klasik}

\section{Uji normlaitas}

Pengambilan kesimpulan untuk menentukan apakah data mengikuti distribusi normal atau tidak adalah dengan menilai nilai siginifikannya. Jika signifikan >0,05 maka variable berdistribusi normal dan sebaliknya jika signifikan $<0,05$ maka variable tidak berdistribusi normal Ghozali (2005).

\section{Uji multikolinearitas}

Untuk melakukan uji multikolinearitas, maka uji statistic yang digunakan yaitu dengan melihat nilai Varian Inflation Factor (VIF) pada model regresi dengan rumusan hipotesis sebagai berikut :

Ho ; r1, r2, r3 = 0 , Tidak punya Korelasi

$\mathrm{Ha} ; \mathrm{r} 1, \mathrm{r} 2, \mathrm{r} 3{ }^{\wedge} 0$, Memiliki Korelasi

Menggunakan $\mathrm{a}=5 \%$

Model regresi yang baik, jika hasil perhitungan menghasilkan nilai VIF $<10$ dan bila nilai VIF > 10 berarti telah terjadi multikolinearitas yang serius didalam model regresi . (Lupiyoadi dan Ikhsan, 2015).

\section{Uji autokorelasi}

Dalam penelitian ini pengujian autokorelasi dilakukan dengan uji Durbin- Watson (DW test). Dengan rumusan hipotesis sebagai berikut :

Ho $; r=0$, tidak ada autokorelasi

$\mathrm{Ha} ; \mathrm{r} \pm 0$, ada autokorelasi

Atau apabila DW terletak diantara batas atas (du) dan (4-du) (du <

DW < 4-du) maka koefisien autokorelasi sama dengan 0 , berarti tidak ada autokorelasi sehingga dapat menggunkan regresi.

\section{Uji heteroskedastisitas}

Model regresi yang baik adalah heteroskedastisitas yang dapat dilihat dari grafik plot antara nilai prediksi variabel terikat (Zpred) dengan residunya (Zresid). Jika pola tertentu, seperti titik-titik yang ada membentuk pola tertentu yang teratur (bergelombang melebar kemudian menyempit), maka mengindikasikan terjadinya heteroskedastisitas. Setelah melewati tahapan diatas, maka data layak menggunakan regresi.

\section{Uji hipotesis}

\section{Uji statistik (F)}

Untuk menguji pengaruh secara bersama-sama (simultan) antara tingkat suku bunga SBI, nilai kurs tengah Rupiah tehadap USD terhadap harga saham pada industry pertambangan batubara periode 2014-2017.dengan rumus : 


$$
F=\frac{R^{2} / K-1}{\left(1-R^{2}\right) /(n-K)}
$$

Adapun langkah-langkah dari uji $\mathrm{F}$ adalah sebagai berikut:

1. Menentukan tingkat signifikansi a $=5 \%(0,05)$

2. Kriteria Keputusan

Jika Sig > 0,05 maka Ho diterima

Jika Sig $<0,05$ maka Ho ditolak

\section{Uji statistik (t)}

Untuk menguji pengaruh secara parsial antara tingkat suku bunga SBI, nilai kurs tengah Rupiah tehadap

USD terhadap harga saham pada industry pertambangan batubara periode 20142017.

Rumusnya $: t=\frac{\beta n}{s \beta n}$

Adapun langkah-langkah uji statistik t adalah sebagai berikut:

1. Tentukan signifikansi dengan $\mathrm{a}=5 \%(0,05)$

2. Kriteria Keputusan

Jika Sig > 0,05 maka Ho diterima

Jika Sig < 0,05 maka Ho ditolak

(Sujarweni 2015)

\section{Koefisien determinasi}

Menurut Ghozali (2005), Koefisien Determinasi (Goodness of fit) yang dinotasikan dengan $R^{2}$ merupakan suatu ukuran yang penting dalam regresi. Determinasi $\left(R^{2}\right)$ mencerminkan kemampuan variabel dependen. Tujuan analisis ini adalah untuk menghitung besarnya pengaruh variabel independen terhadap variabel dependen. Nilai $R^{2}$ menunjukan seberapa besar proporsi dari total variasi variabel tidak bebas yang dapat dijelaskan oleh variabel penjelasnya. Semakin tinggi nilai $R^{2}$ maka semakin besar proporsi dari total variasi variabel dependen yang dapat dijelaskan oleh variabel independen.

\section{HASIL DAN PEMBAHASAN}

\section{Harga saham}

Harga saham merupakan refleksi dari ketutusan- keputusan investasi, pendanaan (termasuk kebijakan deviden), dan pengelolaan asset. Menurut Bambang Riyanto (1997) harga saham merupakan harga yang terjadi di lantai bursa pada harga penutupan yang dinyatakan dalam rupiah.

Berdasarkan data pada Tabel 1 diatas yang diperoleh dari Bursa Efek Indonesia, secara keseluruhan harga saham pada industri pertambangan batubara tersebut mengalami fluktuasi. Antara januari 2014 sampai dengan desember 2017 rata-rata harga saham pada industri pertambangan batubara mencapai titik tertinggi pada bulan januari 2014 yaitu sebesar Rp. 3.738 dan menyentuh titik terendah pada bulan januari 2016 yaitu dengan nominal Rp. 1.734.

Bagian ini akan menjelaskan mengenai hasil perkembangan Harga Saham yang ditunjukkan dalam tabel di bawah ini 
Tabel 1. Perkembangan pertambangan Batubara di Bursa Efek Indonesia, 2014-2017

\begin{tabular}{|c|c|c|}
\hline Bulan/Tahun & Rata-rata Harga Saham & Perkembangan \\
\hline Januari 2014 & 3,739 & \\
\hline Februari 2014 & 3,662 & $-2.06 \%$ \\
\hline Maret 2014 & 3,558 & $-2.85 \%$ \\
\hline April 2014 & 3,602 & $1.25 \%$ \\
\hline Mei 2014 & 2,559 & $-28.95 \%$ \\
\hline Juni 2014 & 2,516 & $-1.69 \%$ \\
\hline Juli 2014 & 3,400 & $35.15 \%$ \\
\hline Agustus 2014 & 3,629 & $6.72 \%$ \\
\hline September 2014 & 3,504 & $-3.45 \%$ \\
\hline Oktober 2014 & 3,206 & $-8.48 \%$ \\
\hline November 14 & 3,120 & $-2.70 \%$ \\
\hline Desember 2014 & 2,879 & $-7.72 \%$ \\
\hline Januari 2015 & 2,900 & $0.71 \%$ \\
\hline Februari 2015 & 2,903 & $0.10 \%$ \\
\hline Maret 2015 & 2,892 & $-0.36 \%$ \\
\hline April 2015 & 2,614 & $-9.64 \%$ \\
\hline Mei 2015 & 2,642 & $1.08 \%$ \\
\hline Juni 2015 & 2,512 & $-4.90 \%$ \\
\hline Juli 2015 & 2,222 & $-11.57 \%$ \\
\hline Agustus 2015 & 2,167 & $-2.46 \%$ \\
\hline September 2017 & 2,130 & $-1.68 \%$ \\
\hline Oktober 2015 & 2,097 & $-1.55 \%$ \\
\hline November 2015 & 1,909 & $-8.98 \%$ \\
\hline Desember 2015 & 1,774 & $-7.07 \%$ \\
\hline Januari 2016 & 1,734 & $-2.28 \%$ \\
\hline Februari 2016 & 1,851 & $6.80 \%$ \\
\hline Maret 2016 & 1,843 & $-0.43 \%$ \\
\hline April 2016 & 1,961 & $6.38 \%$ \\
\hline Mei 2016 & 1,966 & $0.24 \%$ \\
\hline Juni 2016 & 2,102 & $6.92 \%$ \\
\hline Juli 2016 & 2,321 & $10.45 \%$ \\
\hline Agustus 2016 & 2,216 & $-4.52 \%$ \\
\hline September 2016 & 2,055 & $-7.25 \%$ \\
\hline Oktober 2016 & 2,452 & $19.28 \%$ \\
\hline November 2016 & 2,520 & $2.78 \%$ \\
\hline Desember 2016 & 2,634 & $4.53 \%$ \\
\hline Januari 2017 & 2,661 & $1.03 \%$ \\
\hline Februari 2017 & 2,964 & $11.36 \%$ \\
\hline Maret 2017 & 3,209 & $8.26 \%$ \\
\hline April 2015 & 3,187 & $-0.66 \%$ \\
\hline Mei 2017 & 2,830 & $-11.22 \%$ \\
\hline Juni 2017 & 2,996 & $5.86 \%$ \\
\hline Juli 2017 & 3,122 & $4.21 \%$ \\
\hline Agustus 2017 & 3,160 & $1.23 \%$ \\
\hline September 2017 & 3,172 & $0.36 \%$ \\
\hline Oktober 2017 & 3,581 & $12.89 \%$ \\
\hline November 2017 & 3,519 & $-1.71 \%$ \\
\hline Desember 2017 & 3,058 & $-13.11 \%$ \\
\hline$\overline{\text { Rata-rata }}$ & 2,734 & $\mathbf{0}$ \\
\hline
\end{tabular}

Sumber: Data diolah, 2020 


\section{Suku bunga}

Tingkat suku bunga merupakan salah satu intrumen kebijakan yang dikeluarkan Bank Indonesia sebagai bank sentral yang menjalankan kebijakan moneter. Bagian ini akan menjelaskan perkembangan rata-rata tingkat suku bunga Bank Indonesia 2014-2017 yang ditunjukkan tabel dibawah ini

Tabel 2 Tingkat suku bunga SBI Bulanan di Bank Indonesia Periode 2014-2017

\begin{tabular}{lllll}
\hline \multirow{2}{*}{ Bulan } & \multicolumn{4}{c}{ Tingkat Suku Bunga SBI (\%) } \\
\cline { 2 - 5 } & $\mathbf{2 0 1 4}$ & $\mathbf{2 0 1 5}$ & $\mathbf{2 0 1 6}$ & $\mathbf{2 0 1 7}$ \\
\hline Januari & 7.50 & 7.75 & 7.25 & 4.75 \\
Februari & 7.50 & 7.50 & 7.00 & 4.75 \\
Maret & 7.50 & 7.50 & 6.75 & 4.75 \\
April & 7.50 & 7.50 & 5.50 & 4.75 \\
Mei & 7.50 & 7.50 & 5.50 & 4.75 \\
Juni & 7.50 & 7.50 & 5.25 & 4.75 \\
Juli & 7.50 & 7.50 & 5.25 & 4.75 \\
Agustus & 7.50 & 7.50 & 5.25 & 4.75 \\
September & 7.50 & 7.50 & 5.00 & 4.50 \\
Oktober & 7.50 & 7.50 & 4.75 & 4.25 \\
November & 7.50 & 7.50 & 4.75 & 4.25 \\
Desember & 7.75 & 7.50 & 4.75 & 4.25 \\
Rata-rata & 7.52 & 7.52 & 5.58 & 4.60 \\
Perkembangan & & 0 & -25.76 & -17.54 \\
Tertinggi & 7.75 & 7.75 & 7.25 & 4.75 \\
Terendah & 7.50 & 7.50 & 4.75 & 4.25 \\
\hline Sumber:
\end{tabular}

Sumber: www.bi.go.id, 2020(diolah)

Berdasarkan Tabel 2 dapat diketahui bahwa tingkat suku bunga Sertifikat Bank Indonesia Sepanjang Januari 2014 sampai Desember 2017 mengalami penurunan pada setiap tahunnya. Hal ini dapat dilihat pada rata-rata tingkat suku bunga Sertifikat Bank Indonesia setiap tahunnya mengalami penurunan yaitu pada tahun 2016 sebesar $25,76 \%$ dan pada tahun 2017 mengalami penurunan kembali sebesar 17,54\%. Akan tetapi pada tahun tahun 2014 dan tahun 2015 tingkat suku bunga Sertifikat Bank Indonesia tidak mengalami perubahan (stagnan) yaitu tetap bertahan pada rata-rata 7.52\%. Antara Januari 2014 sampai Desember 2017 tingkat suku bunga Sertifikat Bank Indonesia bila dilihat mencapai level tertinggi pada bulan Januari 2015 yaitu sebesar 7.75\% dan menyentuh titik terendah pada bulan Desember tahun 2017 yaitu sebesar $4.25 \%$.

\section{Kurs}

Nilai tukar rupiah (kurs) adalah perbandingan nilai antara mata uang yang menunjukkan harga suatu mata uang jika dibandingkan dengan mata uang lain. Bagian ini akan menjelaskan kurs tengah Rupiah terhadap US Dollar yang ditunjukkan Tabel 3.

Berdasarkan Tabel 3 diketahui perkembangan Nilai Tukar Rupiah terhadap US Dollar di Bank Indonesia selama periode 2014-2017 selalu mengalami fluktuasi setiap tahunnya. Peningkatan terbesar terjadi pada tahun 2016 yaitu sebesar 8,12\% dari tahun sebelumnya dengan nilai rata-rata kurs tengahnya sebesar Rp 13.329,83 pada tahun 2016 yang sebelumnya Rp 12.328,88 pada tahun 2015. Dari tabel 1.1 menunjukkan bahwa Rupiah mengalami depresiasi terhadap USD. 
Jurnal Dinamika Manajemen Vol.7. No.2, Mei-Agustus 2019 ISSN: 2338-123X (print); 2355-8148 (online)

Tabel 3. Nilai tukar rupiah terhadap USD Bulanan di Bank Indonesia, 2014-2017

\begin{tabular}{|c|c|c|c|c|}
\hline \multirow{2}{*}{ Bulan } & \multicolumn{4}{|c|}{ Kurs Tengah } \\
\hline & 2014 & 2015 & 2016 & 2017 \\
\hline Januari & $12,226.00$ & $12,625.00$ & $13,846.00$ & $13,338.50$ \\
\hline Pebruari & $11,634.00$ & $12,863.00$ & $13,395.00$ & $13,347.00$ \\
\hline Maret & $11,404.00$ & $13,084.00$ & $13,276.00$ & $13,316.00$ \\
\hline April & $11,532.00$ & $12,937.00$ & $13,204.00$ & $13,327.00$ \\
\hline Mei & $11,611.00$ & $13,211.00$ & $13,615.00$ & $13,321.00$ \\
\hline Juni & $11,969.00$ & $13,332.00$ & $13,180.00$ & $13,319.00$ \\
\hline Juli & $11,591.00$ & $13,481.00$ & $13,094.00$ & $13,323.00$ \\
\hline Agustus & $11,717.00$ & $13,027.00$ & $13,300.00$ & $13,351.00$ \\
\hline September & $12,212.00$ & $14,567.00$ & $12,998.00$ & $13,492.00$ \\
\hline Oktober & $12,082.00$ & $13,600.50$ & $13,051.00$ & $13,580.00$ \\
\hline November & $12,196.00$ & $13,840.00$ & $13,563.00$ & $13,524.00$ \\
\hline Desember & $12,440.00$ & $1,379.00$ & $13,436.00$ & $13,548.00$ \\
\hline Rata-rata & $11,884.50$ & $12,328.88$ & $13,329.83$ & $13,398.88$ \\
\hline Perkembangan \% & & 3.74 & 8.12 & 0.52 \\
\hline Tertinggi & $12,440.00$ & $14,567.00$ & $13,846.00$ & $13,580.00$ \\
\hline Terendah & $11,404.00$ & $1,379.00$ & $12,998.00$ & $13,316.00$ \\
\hline
\end{tabular}

Sumber : Kurs transaksi Bank Indonesia, 2010 (diolah)

\section{Uji asumsi klasik}

\section{Uji normalitas data}

Berdasarkan Tabel 4 dapat dilihat bahwa dengan menggunakan nilai residual dari ketiga variabel yang diteliti yaiitu harga saham, SBI, dan kurs nilai signifikasinya sebesar 0,188. Jika signifikan > 0,05 maka variable berdistribusi normal dan sebaliknya jika signifikan $<0,05$ maka variable tidak berdistribusi normal. Pada tabel 5.2 nilai signifikasinya sebesar 0.188 , karena nilai signifikasinya $>0,05$ maka variabel berdistribusi normal.

Tabel 4 Hasil uji normalitas data One-Sample Kolmogorov-Smirnov Tes

\begin{tabular}{lll}
\hline & & $\begin{array}{l}\text { Unstandardized } \\
\text { Residual }\end{array}$ \\
\hline $\mathrm{N}$ & & 48 \\
Normal Parameters & & \\
& Mean & .0000000 \\
Most Extreme Differences & Std. Deviation & 440.74252702 \\
& Absolute & .111 \\
& Positive & .111 \\
Test Statistic & Negative & -.100 \\
Asymp. Sig. (2-tailed) & & .111 \\
\hline
\end{tabular}
a. Test distribution is Normal.
b. Calculated from data.
c. Lilliefors Significance Correction.

Sumber: Data diolah, 2020

\section{Uji multikolinearitas}

Berdasarkan Tabel 5 dapat dilihat bahwa besarnya nilai VIF dari variabel tingkat suku bunga sebesar 1.254 dan kurs sebesar 1.254. Jika nilai VIF $<10$ berarti tidak terjadi multikolinearitas dan bila nilai VIF $>10$ berarti telah terjadi multikolinearitas yang serius 
didalam model regresi. Pada tabel 5.3 dilihat bahwa nilai VIF tingkat suku bunga sebesar 1.254 dan nilai kurs sebesar 1.254. karena nilai VIF dari kedua variabel tersebut $<10$ maka tidak terjadi multikolinearitas.

Tabel 5 Hasil uji multikolinearitas

\begin{tabular}{|c|c|c|c|}
\hline & \multirow{2}{*}{ Model } & \multicolumn{2}{|c|}{ Collinearity Statistics } \\
\hline & & Tolerance & VIF \\
\hline \multicolumn{4}{|c|}{1 (Constant) } \\
\hline SBI & & .797 & 1.254 \\
\hline KURS & & .797 & 1.254 \\
\hline
\end{tabular}

Sumber: Data diolah, 2020

\section{Uji autokorelasi}

Berdasarkan Tabel 6 hasil perhitungan dari SPSS dapat dilihat bahwa besarnya nilai Durbin-Watson adalah 0,553. apabila DW terletak diantara batas atas (du) dan (4-du) (du $<$ DW < 4-du) maka koefisien autokorelasi sama dengan 0 , berarti tidak ada autokorelasi sehingga dapat menggunkan regresi.

Tabel 6. Hasil autokorelasi

\begin{tabular}{ccc}
\multicolumn{2}{c}{ Model Summary $^{\mathbf{b}}$} \\
\hline Model & Durbin-Watson \\
\hline 1 & .553 \\
\hline
\end{tabular}

a. Predictors: (Constant), KURS, SBI

b. Dependent variable: harga saham

Sumber: Data diolah, 2020

\section{Uji heteroskedastisitas}

Berdasarkan gambar diata terlihat bahwa titik-titik menyebar secara acak, tidak membentuk pola tertentu yang jelas, serta tersebar baik di atas maupun dibawah angka 0 pada sumbu y. dengan demikian variabel penelitian lulus uji heteroskidastsitas.



Gambar 1. Uji heteroskedastisitas

Berdasarkan gambar diata terlihat bahwa titik-titik menyebar secara acak, tidak membentuk pola tertentu yang jelas, serta tersebar baik di atas maupun dibawah angka 0 pada sumbu y. dengan demikian variabel penelitian lulus uji heteroskidastsitas. 


\section{Uji hipotesis}

Berdasarkan Tabel 7 dapat diketahui bahwa pengaruh tingkat suku bunga SBI dan Kurs terhadap harga saham pada Industri pertambangan batubara di Bursa Efek Indonesia periode 2014-2017 secara simultan menghasilkan Sig $=0.000$, karena Sig < 0.05 maka Ho ditolak dan Ha diterima. Hal ini menunjukkan bahwa tingkat suku bunga SBI dan Kurs secara simultan mempunyai pengaruh yang signifikan terhadap harga saham industri pertambangan batubara di Bursa Efek Indonesia periode 2014-2017.

Tabel 7. Hasil regresi uji statistik (F)

\begin{tabular}{|c|c|c|c|}
\hline & & & \\
\hline Model & $\mathrm{df}$ & $\mathrm{F}$ & Sig. \\
\hline 1 Regression & 2 & 18.032 & $.000^{\mathrm{b}}$ \\
\hline Residual & 45 & & \\
\hline Total & 47 & & \\
\hline
\end{tabular}

a. Dependent Variable: Harga Saham

b. Predictors: (Constant), KURS, SBI

Sumber: Data diolah, 2020

Tabel 8 Hasil Regresi Uji Statistik (t)

\begin{tabular}{lccc}
\multicolumn{4}{c}{ Coefficients $^{\mathrm{a}}$} \\
\hline & Model & $\mathbf{t}$ & Sig. \\
\hline 1 (Constant) & & 7.797 & .000 \\
SBI KURS & -3.221 & .002 \\
& & -5.976 & .000
\end{tabular}

a. Dependent Variable: Harga Saham

Sumber: Data diolah, 2020

Berdasarkan Tabel 8 diperoleh Sig tingkat suku bunga SBI sebesar 0.002, karena Sig $<0.05$ maka Ho ditolak. Ini berarti secara parsial tingkat suku bunga SBI memiliki pengaruh yang signifikan terhadap harga saham industri pertambangan batubara di Bursa Efek Indonesia periode 2014-2017. Hasil ini menunjukkan bahwa jika permintaan tingkat suku bunga SBI mengalami penurunan maka permintaan akan harga saham akan naik. Sehingga para investor cenderung berinvestasi di pasar modal guna mendapatkan keuntungan yang lebih tinggi. Hasil ini sejalan dengan hasil penelitian Tona (2013), bahwa pengaruh tingkat suku SBI memiliki pengaruh yang signifikan terhadap harga saham.

Tabel 9 Koefisien Determinasi untuk Mengetahui Besarnya Perngaruh secara Simultan Model Summaryb

\begin{tabular}{cccc}
\hline $\mathbf{R}$ & R Square & $\begin{array}{c}\text { Adjusted R } \\
\text { Square }\end{array}$ & $\begin{array}{c}\text { Std. Error of the } \\
\text { Estimate }\end{array}$ \\
\hline $.667^{\mathrm{a}}$ & .445 & .420 & 450.43033
\end{tabular}

a. Predictors: (Constant), KURS, SBI

b. Dependent Variable: Harga Saham

Sumber: Data diolah, 2020

Berdasarkan Tabel 9 dengan melihat nilai R Square dapat diketahui besarnya pengaruh tingkat suku bunga SBI dan Kurs secara simultan sebesar 0.445 atau 44,5\%. Hal ini menunjukkan bahwa secara bersama-sama tingkat suku bunga SBI dan Kurs mampu menjelaskan variasi (pola pergerakan) dari harga saham industri pertambangan 
batubara di Bursa Efek Indonesia periode 2014-2017 sebesar 44.5\% . sedangkan 55.5\% dipengaruhi oleh variabel lain yang tidak diteliti dalam penelitian ini.

Tabel 10. Koefisien determinasi untuk mengetahui besarnya perngaruh secara parsial

\begin{tabular}{|c|c|c|}
\hline \multicolumn{3}{|c|}{ Coefficients $^{a}$} \\
\hline Model & $\mathbf{r}^{2}$ & Koef. Determinasi $(\mathrm{R}) R^{2} \times 100 \%$ \\
\hline (Constant) & & \\
\hline SBI & 0.187489 & 18.75 \\
\hline KURS & 0.442225 & 44.22 \\
\hline
\end{tabular}

a. Dependent Variable: Harga Saham

Sumber: Data diolah, 2020

Berdasarkan Tabel 10 dapat dilihat bahwa besarnya pengaruh tingkat suku bunga SBI terhadap harga saham industri pertambangan batubara di Bursa Efek Indonesia periode 2014-2017 adalah sebesar $18.75 \%$. Besarnya pengaruh Kurs terhadap harga saham industri pertambangan batubara di Bursa Efek Indonesia periode 2014-2017 adalah sebesar $44.22 \%$. Secara parsial nilai Kurs lebih besar berpengaruh terhadap terhadap harga saham industri pertambangan batubara di Bursa Efek Indonesia periode 2014-2017 sebesar 44.22\% dibandingkan dengan tingkat suku bunga yaitu sebesar $18.75 \%$.

Hasil ini didapat dengan cara mengkuadratkan nilai partial pada output dari aplikasi SPSS 23

\section{KESIMPULAN DAN SARAN}

\section{Kesimpulan}

Bahwa semua variabel independen yaitu tingkat suku bunga SBI dan Kurs mempunyai pengaruh secara simultan dan signifikan terhadap variabel dependen yaitu harga saham industri pertambangan batubara di Bursa Efek Indonesia periode 2014-2017 dengan koefisien determinasi sebesar 0.445 atau 44,5\%. Hal ini menunjukkan bahwa secara bersama-sama tingkat suku bunga SBI dan Kurs mampu menjelaskan variasi (pola pergerakan) dari harga saham industri pertambangan batubara periode 2014-2017 sebesar 44,5\%. Secara parsial tingkat suku bunga mempengaruhi harga saham industri pertambangan batubara di Bursa Efek Indonesia periode 2014-2017 dengan hasil t hitung -3.221 dan tingkat signifikan 0.002. Hal ini menunjukkan bahwa variabel tingkat suku bunga SBI mempengaruhi harga saham industri pertambangan batubara di Bursa Efek Indonesia periode 2014-2017 secara signifikan, dimana hubungan pengaruhnya berlawanan arah/negatif.

Secara parsial Kurs mempengaruhi harga saham industri pertambangan batubara di Bursa Efek Indonesia periode 2014-2017 dengan hasil t hitung -5.976 dan tingkat signifikan 0.000. Hal ini menunjukkan bahwa variabel Kurs mempengaruhi harga saham industri pertambangan batubara di Bursa Efek Indonesia periode 2014-2017 secara signifikan, dimana hubungan pengaruhnya berlawanan arah/negatif.

Berdasarkan koefisies determinasi parsial diketahui bahwa nilai Kurs merupakan nilai paling dominan mempengaruhi harga saham industri pertambangan batubara di Bursa Efek Indonesia periode 2014-2017 yaitu sebesar 44.22\% dibandingkan dengan variabel tingkat suku bunga SBI sebesar $18.75 \%$.

\section{Saran}

Berdasarkan hasil penelitian yang dilakukan, maka peneliti memberikan saransaran yang berhubungan dengan penelitian sebagai berikut :

Bagi para investor, yang akan menginvestasikan dananya di pasar modal hendaknya 
memperhatikan tingkat suku bunga SBI dan Kurs dalam mengalokasikan dananya. Diketahui bahwa tingkat suku bunga SBI dan Kurs secara simultan berpengaruh signifikan terhadap harga saham industri pertambangan batubara yang merupakan saham likuit setiap tahunnya dipasar modal Indonesia.

Diharapkan kepada investor ataupun calon investor yang ingin menanamkan modalnya ke pasar modal untuk lebih memperhatikan nilai tukar Kurs, karena nilai tukar paling dominan dibandingkan dengan tingkat suku bunga SBI yang mempengaruhi signifikasi secara simultan dan parsial terhadap harga saham industri pertambangan batubara. Dengan melemahnya nilai Dollar AS terhadap Rupiah memberikan tanda bahwa perekonomian Indonesia sedang membaik dan investor akan menanamkan dananya di pasar modal Indonesia. Sebaliknya jika nilai Dollar AS terhadap Rupiah menguat, maka investor akan enggan menanamkan modalnya di pasar modal Indonesia dan mencari alternatif investasi lain. Penelitian ini diharapkan dapat digunakan sebagai bahan refereensi bagi penelitian selanjutnya dengan menambahkan variabel bebas lainnya agar variabel ekonomi makro terhadap harga saham dapat dijelaskan lebih baik lagi.

\section{DAFTAR PUSTAKA}

Adib, A. M. (2009). Pengaruh Inflasi, Suku Bunga Doemstik, Suku Bunga Luar Negeri dan Kurs Terhadap Indeks Harga Saham (Studi Pada JII dan IHSG Tahun 20052007).

Gunawan, J. L. (2014). Pengaruh Inflasi, Suku Bunga Sbi, Pdb Dan Nilai Tukar Terhadap Indeks Harga Saham Gabungan (Ihsg) Di Bursa Efek Indonesia Tahun 2000-2014.

Hartono jogianto, 2016. Teori Portofolio dan Analisis Investasi. Edisi kesepuluh. BPFE, Y ogyakarta.

Kasmir, (2010). Pengantar Manajemen Keuangan. Edisi Pertama, Kencana,Jakarta.

Kewal, S. S. (2012). Pengaruh inflasi, suku bunga, kurs, dan pertumbuhan PDB terhadap indeks harga saham gabungan. Jurnal economia, 8(1), 53-64.

Laurensia Sonta. P dan Desi Anita. (2014). Analsis pengaruh operatingprofit margin $(O P M)$, return on equity (ROE), earning per share (EPS), nilai tukar rupiah (Kurs) dan iniflasi terhadap harga saham pada perusahaan garment dan tekstil yang terdaftar di Bursa Efek Indonesia (BEI). Program Studi Manajemen Sekolah Tinggi Ilmu Ekonomi Pelita Indonesia.

Lubis, T. A., \& Riyadi, A. (2013). Pengaruh inflasi, suku bunga, dan kurs terhadap indeks LQ45 di Bursa Efek Indonesia Priode 2007-2011. Jurnal Dinamika Manajemen, 1(3), 183-197.

Lupiyoadi, R., \& Ikhsan, R. B. (2015). Praktikum metode riset bisnis. Jakarta: Salemba Empat, 306.

Prabowo, H., Wahono, B., \& ABS, M. K. (2017). Pengaruh inflasi, tingkat suku bunga, nilai tukar rupiah terhadap dolar amerika terhadap harga saham (perusahaan industri tekstil dan garmen yang tercatat di Bursa Efek Indonesia Periode Tahun 2013-2015). Jurnal Ilmiah Riset Manajemen, 6(03).

Saputra, E. (2017). Pengaruh nilai tukar mata uang, inflasi, dan suku bunga terhadap harga saham sektor properti di Bursa Efek Indonesia (Doctoral dissertation, STIESIA SURABAYA).

Sujarweni, V. W. (2015). Metodologi penelitian: bisnis \& ekonomi. Yogyakarta: Pustakabarupress

Tandelilin, E. (2001). Analisis investasi dan manajemen portofolio. Edisi Pertama,. Yogyakarta: BPFE-Yogyakarta. 